\title{
Soil Carbon: An Overview on Soil Carbon Function and its Fractionation
}

\author{
KUMARI PRIYANKA ${ }^{* 1}$ and ANSHUMALI ${ }^{1}$ \\ Department of Environmental Science \& Engineering, \\ Indian School of Mines, Dhanbad-826004, Jharkhand, India. \\ http://dx.doi.org/10.12944/CWE.11.1.22
}

(Received: December 11, 2015; Accepted: February 09, 2016)

\begin{abstract}
The atmospheric carbon reservoir is significantly affected by change in lithogenic carbon reservoir. Carbon reservoir of soil is strongly influenced by the interaction between different biogeochemical cycles and environmental processes. At the local scale land use and soil management have also a significant impact on the soil carbon pool. Soil carbon is the major determinant of soil quality and agronomic viability because of its influence on other soil features. Different fractionation procedure is often described in terms of the soil organic matter (SOM) pool sizes, chemical properties, and turnover rates. Soil carbon separation includes physical and chemical methods and their combinations in a sequence. Separation of soil carbon according to soil aggregate size, density and magnetic properties is termed as physical separation whiles their solubility, oxidizability, hydrolysability is used in chemical fractionation. Carbon fractionation is a useful tool for observing the changes in different labile, recalcitrant and total pool of soil carbon. Thus, helpful in making decision to locals for adopting proper management practices suitable for a particular soil type in response to economic productivity and soil quality.
\end{abstract}

Key words: Soil Organic Carbon, Management Practices, Aggregate, Fractionation.

\section{INTRODUCTION}

Carbon is stored within soil mainly in two forms, soil inorganic carbon and soil organic carbon. The source of inorganic carbon (IC) in the soil is either parent rock material or the dissolution and precipitation of carbonate. SIC has relatively a longer turnover time because of lower activity, but redistribute rapidly in a short time period under high microbial activity ${ }^{1,2}$. Organic carbon forms of soil are the residues of plants and animals. Soil carbon ranges from freshly deposited plant debris to highly resistant forms such as humus. Soil carbon participates in nutrient cycling, grain yield and various other soil functioning $3,3,5,5,6,7,8$. The turn over rate of SOM influences the biogeochemical transformation of nutrients and stability of soil structure $^{9}$. SOM is categorise into diverse groups by their turn over rates and their regulatory elements ${ }^{10}$. Carbon fractions with higher turn over rate such as particulate organic carbon, potentially mineralizable carbon, microbial biomass carbon, and $\mathrm{KMnO} 4$ oxidizable carbon are more superficial to forecast changes in SOC dynamics than the total SOC $^{11,12,13}$. Soil organic carbon was classified into different fractions by their protection covering into protected (physical and biochemical protection) and unprotected organic carbon ${ }^{14}$. SOM is a mixture of substance that diverges in nutrient content and also reflects dynamicity because of its continuous changes in turnover time ${ }^{15}$. SOM is a collection of a number of carbon pools whose decomposition rate is ranging from a year (very active) to thousands of years (stable) ${ }^{16,17}$. Labile soil organic carbon fractions, decompose relatively easily and have a greater turnover rate as compared with recalcitrant 
organic $C$ fractions ${ }^{18}$. They are not only involved in the biogeochemical transformation of nutrients such as $\mathrm{N}, \mathrm{P}$ and $\mathrm{S}$, but also contribute to soil structure and stabilization ${ }^{19}$. Labile organic $C$ fractions react more rapidly to changes in the environment or pollution than recalcitrant organic carbon, and are thus acting as the primary indicator of soil quality $20,21,22$.

\section{Soil Carbon Fractionation}

Soil carbon fractionation is separation of soil organic matter into diverse pools based on their inherent properties ${ }^{1,23}$. Carbon fraction with relatively larger turn over rate acts as quick and sensitive indicator of soil quality dynamics ${ }^{24,21,18}$. The main drawbacks of organic carbon as an sensitive indicator of changes in soil quality is its testing ability, i.e. change in SOC in response to fluctuations in controlling factors, due to the longer turn over time and the large amount of stable organic carbon already present in soil ${ }^{11}$. Use of subparts, or fractions, of carbon as sensitivity indicator, makes soil carbon pool, very useful for estimating the impact of different management practices on soil carbon $^{25,26,27 .}$

Each fraction of SOC may differ in size, composition, Physico-chemical properties and rate of decomposition. Microclimate of soil such as soil type, water availability and management practices can influence the amount, relative stability and biological availability of carbon stored in the different fractions. Soil carbon fractionation provides an overview of plant function with a property of controlling overall quality and quantity of litter. Soil carbon composition and turnover is influenced by land management, relations between living and non-living elements, and associated rates of biogeochemical cycles. Intrinsic properties of discrete fractions, their degree of stability and location in the soil matrix also influences composition of a particular SOM fraction. Soil carbon fractionation is helpful for evaluating carbon di oxide releases, the capability of soils for carbon storage in response to climate change. Different soil carbon fractions with an ability to rapidly change in response to different management practices proves as an efficient tool to identify optimized agricultural management practices that results in the increase in quality and quantity of soil carbon.

\section{Carbon Pools in Different Size Aggregates}

Different carbon pools influence aggregation differently and also SOM is influenced by aggregate turn over ${ }^{28,29,30,31}$. Thus $\mathrm{C}$ content in aggregates and their size are interdependent. C pools in soil aggregates provide substantial view on decomposition and the storage capacity of carbon in different aggregate size fractions. Suitable management practices help in protection of carbon pools in soil aggregates. The distribution of the C fraction among soil aggregate size fractions is variable $^{32,33}$. On the basis of turn over time $C$ pool is classified as Active, Slow and Intermediate pools. Active pools change seasonally and influence aggregation ${ }^{34,35}$. Soil carbon concentrations alter gradually over time because of their bulk quantity ${ }^{36}$. Particulate organic carbon is reflected as transitional pools in soil carbon dynamics and acts as a substrate for microbial activity ${ }^{28,36,29}$.

\section{Soil Organic Carbon as an Indicator of Soil Quality}

Physical, chemical, and biological fractions of SOC pools provide a sensitive indication of changes in the SOC dynamics relative to total soil carbon alone. Soil biological quality can be used as a sensitive indicator of soil quality evaluation, including soil carbon sequestration in response to sustainable management practices ${ }^{37}$. The carbon dynamics also depends on the microbial population, the intrinsic properties of plants and the availability of nutrients ${ }^{38}$. Soil microbes tangibly organise soil particles together and enrich soil clump which protects C in macro aggregates ${ }^{39,40}$. Soil organic matter is physically protected within aggregates ${ }^{41}$. Aggregates have a major impact on microbial community structure, gaseous exchange, water maintenance and nutrient cycling ${ }^{42}$. Soil structure consisted of free primary particles (sand, silt, and clay), micro aggregates, and macro aggregates as a physical unit of aggregates. Binding forces responsible for their aggregation are mainly microbial and plantderived carbohydrates in association with different metals and compounds ${ }^{43}$. Increase in organic carbon increases soil aggregate stability. Fresh residue is a base of soil aggregation by providing $\mathrm{C}$ source for microbial activity and the creation of clumping agents as a by-product. Microscopic populations and their functions fluctuate in aggregate fractions of different sizes ${ }^{44}$.Soil aggregates have a high 
variation in microbial communities and activities at a microbial scale and binding of organic matter within soil aggregates also report long-lasting variations in $\mathrm{C}$ pools in soil aggregates ${ }^{45}$. Soil aggregation influences conservation and mineralization of carbon $^{43}$. Macroaggregates are fractions of larger than 250 micro $\mathrm{m}$ size and are composed of organic residues and coarse sand coated with a clay matrix. These macro-aggregates were colonized by numerous microorganisms ${ }^{46}$. Macro aggregate organic matter content decreased with cultivation ${ }^{47}$. Long-term cropping decreases the soil organic matter and caused a reduction in macro aggregation, but micro aggregation was relatively unaffected $^{48}$. Macro aggregates have more organic $\mathrm{C}, \mathrm{N}$, and $\mathrm{P}$, than microaggregates. Microaggregates (20 to 250 micro $\mathrm{m}$ size fractions) are the building blocks of soil structure and become united to form macroaggregates. Organic matter concentration of microaggregates was considerably less than that of macroaggregate in soils. Microaggregates have more $\mathrm{N}$ and $\mathrm{P}$ than $\mathrm{C}$. Microaggregates are rich in organic matter which are highly processed, humified, old, passive and recalcitrant ${ }^{49,50,51}$.

\section{Effect of Management Practices on SOC Pool}

The soil properties vary widely in differently managed ecosystems results in variations in soil functioning ${ }^{52,53,54,55}$. Inappropriate management of soil leads to soil erosion, exhaustion of organic matter and other nutrients which results in permanent soil mortification and efficiency losses ${ }^{56,57}$.

For the sustainable growth of both productivity and soil fertility, a good management practices are essential ${ }^{40}$. A variation in management practices results in alterations in quality and quantity of soil carbon ${ }^{58,59}$. Conventional management practices include plowing, chisel plowing and multiple tillage trips. Conventional tillage incorporates residues into soil, thereby increases soil-residue contact, favouring rapid decomposition of soil organic matter ${ }^{60}$. Incorporation of soil residues results in an optimum level of moisture and temperature with proficient microbial population, healthier soil structure and significant enhancement in soil qualities and thus decreases the degradation of carbon $^{61}$. Soil biological, chemical and physical quality, enhanced in No-tillage and degraded under conventional tillage under a certain period of time $62,63,64,65,66,67$. According to Lee et al., tillage can physically disrupt the soil aggregates and decreases its stability ${ }^{68}$. Conservation management practices include putting off the remains of plant biomass on an uninterrupted surface which greatly enhances C accumulation within soil aggregates. Increased tillage intensity in many conventional tillage systems decreases total carbon, particularly active carbon and increases catabolism of carbon by disrupting soil aggregates and exposure of aggregate protected $\mathrm{C}$ to microbial attack ${ }^{69}$. The adoption of conservation tillage practices offers soil carbon sequestration opportunity, more favourable plant growth environment and soil health improvement relative to conventional tillage ${ }^{70}$. Conservation tillage practices prevent the loss of SOC ${ }^{71,72}$. Among the conservation and conventional management practices, the conservation management practices implemented better to develop soil quality properties over time. No-till greatly enhances long term carbon conservation within different sizes of soils ${ }^{73,74}$.

\section{Role of Organic Carbon in Productivity of Soil}

Soil has an ability of renovation and accumulation of nutrients and their kinetics. The efficiency of an Agro-ecosystem depends on its productivity. SOM supports ecosystem function in terrestrial systems. Recalcitrant materials with lengthier residence times observably involve the major pools in soils. SOC has the capability to control water and air movement. SOC is closely associated with the soil's biological and physical status. Physico-chemical reactivity of soil is also influenced by the SOC. Soil carbon plays a vital role in regulating ecosystem services. Management systems influence all the internal and interrelated properties of soil over time ${ }^{75}$. Soil management practices to obtain various socio-economic and environmental benefits requires decisive action that maintains and enhances soil carbon. Integrated policies and incentives are required to limit soil carbon loss due to bad management practices that results in loss and discharges of greenhouse gases to the atmosphere ${ }^{76}$. Soils are vulnerable to carbon losses and results in the release of carbon dioxide to the atmosphere as a consequence of accelerated degradation due to land use change or unsustainable management practices ${ }^{77}$. Microorganisms presented in the soil produce certain substances that act as binding material for soil particles ${ }^{78}$. These soil 
aggregates acts as a store house of soil carbon and also helps in the stabilization of soil carbon. Soil carbon is very essential for soil aggregate stability and plant nutrient intake ${ }^{7,8}$. If more carbon is stored in the soil as organic matter, it will result in reduction of atmospheric carbon, which means reduction of greenhouse gases and global warming. The storage of carbon in soil as soil organic matter is called 'soil carbon sequestration'.

\section{Advantages to Increasing or Maintaining a High Level of SOM}

Soil organic carbon is the principal associate of soil productiveness. It reserves and discharges nutrients for plant and microbial growth, stimulates the soil structure, healthiness of soil, and acts as a buffer against harmful substances. Carbon present in the organic material expands drought resistance of soil, structural stability and protects it from soil erosion ${ }^{79}$. Soil organic matter acts as a reservoir of nutrients and is a buffer against harmful substances. Soil organic matter is vital for crop productivity and proliferation of soil microbes, promotes the structure, physical and biological health by providing food and substrate ${ }^{80}$.A direct increase in productivity is observed in response of increasing the carbon content of soil by adopting various management practices ${ }^{81}$. There is a limit of storage capability of soil; soil, limited in carbon content has the potential to capture and store carbon. Soil organic carbon is important for the soil health and sustainable agriculture. Organic carbon in soil plays an important role in providing a suitable environment for proper growth of plants like improving resistivity for pests and diseases by making them healthier and acting like a reservoir of water during drought period because of its property of sponginess.

\section{CONCLUSION}

Soil management practices affect soil carbon pools. Various management practices like the addition of appropriate manure, no-tillage and crop rotation can be utilised to increase soil productivity by increasing carbon inputs. Soil carbon fractionation is helpful for predicting trace gas emissions in the atmosphere and ecosystem dynamics in the lithosphere, in response to climate change. The fractionation procedure can be used to determine the state and the rate of change in carbon of different soil systems. For increasing SOC in soil, certain conservation practices may be adopted. Management and improvement of soil quality are imperative for the vastly growing population who conservatively depends on the soil resources for a constant supply of food and fibre. There is a need for farmers to be made aware them about the facts of soil carbon in agriculture so they can make a proper decision for adopting a suitable management practices for enhancement of productivity and fertility of soil simultaneously.

\section{ACKNOWLEDGEMENTS}

The authors are thankful to the Ministry of Human Resource Development, Government of India for funding the research work. We are also grateful to the Department of Environmental Science and Engineering, Indian School of Mines, Dhanbad for providing the logistic support to carry out field monitoring and laboratory analysis.

\section{REFERENCES}

1. Amundson, R., The Carbon Budget in Soils. Annual Review of Earth and Planetary Sciences, 29(1): 535-62 (2001)

2. Cerling, T. E., Quade, J., Wang, Y., \&Bowman, J. R., Carbon isotopes in soils and paleosols as ecology and paleoecology indicators. Nature, 341: 138-139 (1989)

3. Bhattacharyya, R., Kundu, S., Prakash, V.,\& Gupta, H. S., Sustainability under combined application of mineral and organic fertilizers in a rainfed soybean-wheat system of the
Indian Himalayas. Eur. J. Agron., 28(1): 33-46 (2008)

4. Bhattacharyya, R., Kundu,S., Prakash, V.,\& Gupta, H. S., Long term effects of fertilization on carbon and nitrogen sequestration and aggregate associated carbon and nitrogen in the Indian sub-Himalayas. Nutr. Cycling Agroecosyst.,86: 1-16 (2010)

5. Manna, M. C., Swarup, A., Wanjari, R. H., Mishra, B., \&Shahi, D. K., Long-term fertilization, manure and liming effects on soil 
organic matter and crop yields. Soil Tillage Res., 94(2): 397-409 (2007)

6. Rasool, R., Kukal, S. S., \&Hira, G. S., Soil organic carbon and physical properties as affected by long-term application of FYM and inorganic fertilizers in maize-wheat system. Soil Tillage Res., 101(1-2): 31-36 (2008)

7. Krishan, G., Srivastav, S.K., Kumar, S., Saha, S.K. \& Dadhwal, V.K., Quantifying the underestimation of soil organic carbon by the Walkley and Black technique - examples from Himalayan and Central Indian soils. Current Science, 96(8), 1133-1136 (2009)

8. Velmurugan, A., Krishan, G., Dadhwal, V.K., Kumar, S., Swarnam, T.P. \& Saha, S.K., Harmonizing soil organic carbon estimates in historical and current data. Current Science, 97(4): 554-558 (2009)

9. Lagomarsino, A., Moscatelli, M. C., Tizio, D. A., Mancinelli, R., Grego, S., \&Marinari, S., Soil biochemical indicators as a tool to assess the short-term impact of agricultural management on changes in organic $\mathrm{C}$ in a Mediterranean environment. Ecol. Indic., 9: 518-527 (2009)

10. Cambardella, C. A., \& Elliott, E. T., Particulate soil organic-matter changes across a grassland cultivation sequence. Soil Sci. Soc. Am. J., 56(3): 777-783 (1992)

11. Wu, J., \&Brookes, P. C., The proportional mineralisation of microbial biomass and organic matter caused by air-drying and rewetting of a grassland soil. Soil Biology \& Biochemistry, 37: 507-515 (2005)

12. Campbell, C. A., Janzen, H. H., \&Juma, N. G., Case studies of soil quality in the Canadian Prairies: long-term field experiments. Dev. Soil Sci., 25: 351-397 (1997)

13. Blair, G. J., Lefroy, R. D. B., \&Lise, L., Soil carbon fractions based on their degree of oxidation, and the development of a carbon management index for agricultural systems. Aust. J. Agric. Res., 46(7): 1459-1466 (1995)

14. Six, J., Callewaert, P., Lenders, S. D., Gryze, S., Morris, S. J., Gregorich, E. G., Paul, E. A., \&Paustian, K., Measuring and understanding carbon storage in afforested soils by physical fractionation. Soil Sci. Soc. Am. J., 66(6): 1981-1987 (2002)
15. Oades, J., The retention of organic matter in soils. Biogeochemistry, 5(1): 35-70 (1988)

16. Campbell, C. A., Paul, E. A., Rennie, D. A.,\& McCallum, K. J., Applicability of the Carbon-Dating Method of Analysis to Soil Humus Studies. Soil Science, 104(3): 217-24 (1967)

17. Hsieh, Y. P., Pool size and mean age of stable soil organic carbon in cropland. Soil Science Society of America Journal,56: 460-464 (1992)

18. Mc. Lauchlan, K. K., \& Hobbie, S. E., Comparison of labile soil organic matter fractionation techniques. Soil Sci. Soc. Am. J., 68: 1616-1625 (2004)

19. Lagomarsino, A., Grego, S., Marhan, S., Moscatelli, M. C., \&Kandeler, E., Soil Management Modifies Micro scale Abundance and Function of Soil Microorganisms in a Mediterranean Ecosystem. European Journal of Soil Science, 60(1): 2-12 (2009)

20. Haynes, R. J., Labile Organic Matter as an Indicator of Organic Matter Quality in Arable and Pastoral Soils in New Zealand. Soil Biology and Biochemistry, 32(2): 211-19 (2000)

21. Ghani, A., Dexter, M., \&Perrott, K. W., HotWater Extractable Carbon in Soils: A Sensitive Measurement for Determining Impacts of Fertilisation, Grazing and Cultivation.Soil Biology and Biochemistry, 35(9):1231-43 (2003)

22. Powlson, D. S. The soil microbial biomass: Before, beyond and back. In 'Beyond the Biomass'. K Ritz, J Dighton, KE Giller, Eds., 3-20 (1994).

23. Denef, K., Plante, A. F., \& Six, J., Characterization of Soil Organic Matter, In: W. L. Kutsch, M. Bahn and A. Heinemeyer, Eds., Soil Carbon Dynamics: An Integrated Methodology, Cambridge University Press, Cambridge, 91-126 (2009)

24. Powlson, D. S., The soil microbial biomass: before, beyond and back. In: Ritz, John Wiley \& Sons, Chichester, UK, 3-20 (1994)

25. Galdos, M. V., Cerri, C. C., \&Cerri, C. E. P., Soil carbon stocks under burned and unburned sugarcane in Brazil. Geoderma, 153:347-352 (2009)

26. Graham, M. H., \&Haynes, R. J., Organic matter 
status and the size, activity and metabolic diversity of the soil microbial community in the row and inter-row of sugarcane under burning and trash retention.Soil Biol. Biochem., 38: 21-31 (2006)

27. Skjemstad, J. O., Taylor, J. A., Janik, L. J., \&Marvanek, S. P., Soil organic carbon dynamics under long-term sugarcane monoculture.Aust. J. Soil Res., 37: 151-164 (1999)

28. Beare, M. H., Hendrix, P. F., Cabrera, M. L., \& Coleman, D. C., Aggregate-protected and unprotected organic matter pools in conventional-and no-tillage soils. Soil Science Society of America Journal, 58(3): 787-795 (1994)

29. Six, J., Elliott, E. T., \& Paustian, K., Aggregate and soil organic matter dynamics under conventional and no-tillage systems. Soil Science Society of America Journal, 63(5): 1350-1358 (1999)

30. Gale, W. J., Cambardella, C. A., \& Bailey, T. B., Root-derived carbon and the formation and stabilization of aggregates. Soil Science Society of America Journal, 64(1): 201-207 (2000)

31. Elliott, J. Six, E. T.,Paustian, K., \& Doran, J.W., Aggregation and Soil Organic Matter Accumulation in Cultivated and Native Grassland Soils. Soil Science Society of America Journal, 62: 1367-77 (1998)

32. Sainju, U. M., Terrill, T. H., Gelaye,S., \&Singh, B. P.,Soil aggregation and carbon and nitrogen pools under rhizoma peanut and perennial weeds. Soil Sci. Soc. Am. J., 67: 146-155 (2003a)

33. Sainju, U. M., Whitehead, W. F.,\&Singh, B. P., Cover crops and nitrogen fertilization effects on soil aggregation and carbon and nitrogen pools. Can. J. Soil Sci., 83: 155-165 (2003b)

34. Franzluebbers, A. J., \& Arshad, M. A., Soil microbial biomass and mineralizable carbon of water-stable aggregates. Soil Science Society of America Journal, 61(4): 1090-1097 (1997)

35. Jastrow, J. D., Miller, R. M.,\& Lussenhop, J., Contributions of interacting biological mechanisms to soil aggregate stabilization in restored prairie. Soil Biology and Biochemistry, 30(7): 905-916 (1998)
36. Franzluebbers, A. J., Potential C and $\mathrm{N}$ mineralization and microbial biomass from intact and increasingly disturbed soils of varying texture. Soil Biology and Biochemistry, 31(8): 1083-1090 (1999)

37. Aziz, I., Mahmood, T., \& Islam, K. R., Effect of long term no-till and conventional tillage practices on soil quality. Soil and Tillage Research, 131: 28-35 (2013)

38. Breulmanna, M., Masyutenko, N. P., Kogutc, B. M., Schrolld, R., Dörflerd, U., François Buscote, F.,\&Schulz, F.,Short-Term Bioavailability of Carbon in Soil Organic Matter Fractions of Different Particle Sizes and Densities in Grassland Ecosystems. The Science of the total environment, 497-498: 29-37 (2014)

39. Kennedy, A. C., \& Papendick, R. I., Microbial characteristics of soil quality. Journal of soil and water conservation, 50(3): 243-248 (1995)

40. Aziz, I., Mahmood, T., Raut, Y., Lewis, W., Islam, R., \&Weil, R. R., Active organic matter as a simple measure of field soil quality. In: ASA International Meetings, Pittsburg, PA (2009)

41. Tisdall, J. M., \& Oades, J., Organic matter and water stable aggregates in soils. Journal of soil science, 33(2): 141-163 (1982)

42. Sexstone, A. J., Revsbech, N. P., Parkin, T. B., \& Tiedje, J. M., Direct measurement of oxygen profiles and denitrification rates in soil aggregates. Soil science society of America journal, 49(3): 645-651 (1985)

43. Six, J., Paustian, K., Elliott, E.T. and Combrink, C., Soil structure and organic matter I. Distribution of aggregate-size classes and aggregate-associated carbon. Soil Science Society of America Journal, 64(2), 681689(2000)

44. Elliott, E.T., Aggregate structure and carbon, nitrogen, and phosphorus in native and cultivated soils. Soil Science Society of America Journal, 50(3), 627-633 (1986)

45. Groenigen, V., K.J., Harris, D., Horwath, W.R., Hartwig, U.A. and Van Kessel, C., Linking sequestration of $13 \mathrm{C}$ and $15 \mathrm{~N}$ in aggregates in a pasture soil following 8 years of elevated atmospheric CO2. Global Change Biology, 8(11), 1094-1108 (2002) 
46. Bach, E. M.,\& Kirsten, S. H., Soil Aggregate Isolation Method Affects Measures of IntraAggregate Extracellular Enzyme Activity. Soil Biology and Biochemistry, 69:54-62 (2014)

47. Tisdall, J.M., \& Oades, J.M., The effect of crop rotation on aggregation in a red-brown earth. Aust. J. Soil Res., 18: 423- 433 (1980a)

48. Tisdall, J. M., \& Oades, J. M., The management of ryegrass to stabilize aggregates of a redbrown earth. Aust. J. Soil Res., 18: 415-422 (1980b)

49. Paul, E.A., Dynamics of organic matter in soils. Plant Soil, 76: 275-285 (1984)

50. Parton, W.J., Anderson, D.W., Cole, C.V., \& Stewart, J.W.B., Simulation of organic matter formation and mineralization in semiarid agroecosystems. p. 533-550. In: R.R. Lowrance et al. (Eds.) Nutrient cycling in agricultural ecosystems. Spec. Pub. no.23. The University of Georgia Press, Athens (1983)

51. Van Veen, J.A., \& Paul, E.A., Organic carbon dynamics in grassland soils. 1. Background information and computer simulation. Can. J. Soil Sci., 61: 185-201 (1981)

52. Islam, K. R., \& Weil, R. R., Land use effects on soil quality in a tropical forest ecosystem of Bangladesh. Agriculture, Ecosystems \& Environment,79(1): 9-16 (2000)

53. Wolfarth, F., Schrader, S., Oldenburg, E., Weinert, J., \& Brunotte, J., Earthworms promote the reduction of Fusarium biomass and deoxynivalenol content in wheat straw under field conditions. Soil Biology and Biochemistry, 43(9): 1858-1865 (2011)

54. Celik, I., Barut, Z.B., Ortas, I., Gok, M., Demirbas, A., Tulun, Y., \& Akpinar, C., Impacts of different tillage practices on some soil microbiological properties and crop yield under semi-arid Mediterranean conditions. International Journal of Plant Production, 5(3): 237-254 (2011)

55. Ding, W. X., Hongyan, Y. Y., \& Cai, Z. C., Impact of urease and nitrification inhibitors on nitrous oxide emissions from fluvo-aquic soil in the North China Plain. Biology and Fertility of Soils, 47(1): 91-99 (2011)

56. Ramos, M. E., Robles, A. B., Sánchez-Navarro, A., \& González-Rebollar, J. L., Soil responses to different management practices in rainfed orchards in semiarid environments. Soil and Tillage Research, 112(1): 85-91 (2011)

57. Krishan, G., Kushwaha, S.P.S. \& Velmurugan, A., Land degradation mapping in the upper catchment of river Tons. Journal of the Indian Society of Remote Sensing, 37(1): 119-128 (2009)

58. Cambardella, C. A., \& Elliott, E. T., Carbon and nitrogen distribution in aggregates from cultivated and native grassland soils. Soil Science Society of America Journal, 57(4): 1071-1076 (1993)

59. Schulz, E., Influence of site conditions and management on different soil organic matter (SOM) pools. Archives of Agronomy and Soil Science, 50(1): 33-47 (2004)

60. Campbell, C. A., McConkey, B. G., Zentner, R. P., Selles, F., \& Curtin, D., Tillage and crop rotation effects on soil organic $\mathrm{C}$ and $\mathrm{N}$ in a coarse-textured Typic Haploboroll in southwestern Saskatchewan. Soil and Tillage Research, 37(1): 3-14 (1996)

61. Krishan, G., Kumar, S., Saha, S.K. \& Sardar, A.K., Role of crop residue in organic farming. Annals of Forestry, 14 (2): 355-359 (2006)

62. Madejon, E., Murillo, J.M., Moreno, F., Lopez, M.V., Alvaro-Fuentes, J., \& Cantero, Effect of long-term conservation tillage on soil biochemical properties in Mediterranean Spanish areas. Soil and Tillage Research, 105: 55-62 (2009)

63. Naudin, K., Goze, E., Balarabe, O., Giller, K.E., \& Scope, E., Impact of no tillage and mulching practices on cotton production in North Cameroon: a multi-locational on-farm assessment. Soil and Tillage Research, 108: 68-76 (2010)

64. Derpsch, R., Friedrich, T., Kassam, K., \& Hongwen, L., Current status of adoption of no-till farming in the world and some of its main benefits. International Journal of Agricultural and Biological Engineering, 3(1): 1-25 (2010)

65. Moussa-Machraoui, S., Errouissi, F., BenHammouda, M., Nouira, S., Comparative effects of conventional and no-tillage management on some soil proper- ties under Mediterranean semi-arid conditions in northwestern Tunisia. Soil and Tillage Research, 106: 247-253 (2010) 
66. Benitio, A., Carbon accumulation in soil. Ten year study of conservation tillage and crop rotation in a semi-arid areas of Castile-Leon, Spain Aurora Sombrero. Soil and Tillage Research, 107: 64-70 (2010)

67. Alvaro-Fuentes, J., Joaquýn Morell, F., PlazaBonilla, D., Arrue, J., \& Cantero-Martinez, C., Modelling tillage and nitrogen fertilization effects on soil organic carbon dynamics. Soil and Tillage Research, 120:32-39 (2012)

68. Lee, J., Hopmans, J. W., Rolston, D. E., Baer, S. G., \& Six, J., Determining soil carbon stock changes: simple bulk density corrections fail. Agriculture, Ecosystems \& Environment, 134(3): 251-256 (2009)

69. Mikha, M. M., \& Rice, C. W., Tillage and manure effects on soil and aggregateassociated carbon and nitrogen. Soil Science Society of America Journal, 68(3): 809-816 (2004)

70. Awale, R., Chatterjee, A., \&Franzen D., Tillage and $\mathrm{N}$-fertilizer influences on selected organic carbon fractions in a North Dakota silty clay soil. Soil and Tillage Research,134: 213-222 (2013)

71. Cihacek, L. J., \&UImer, M. G., Effects of tillage on profile soil carbon distribution in the Northern Great Plains of the U.S. In: Lal, R., et al. (Eds.), Management of Carbon Sequestration in Soil. Lewis Publishers, CRC press, Boca Raton, New York, 83-91 (1998)

72. Halvorson, A.D., Weinhold, B.J., \& Black, A.L., Tillage, nitrogen, and cropping system effects on soil carbon sequestration. Soil Science Society of America Journal, 66: 906-912 (2002)

73. Shan, H., Yan-Ni, S., Wen-Yi, R., Wu-Ren, L., Wei-Jian, Z., Long-term effect of no-tillage on soil organic carbon fractions in a continuous maize cropping system of northeast China. Soil Science Society of China, 20(3): 285-292 (2010)

74. Erkossa, T., Tillage effects on physical qualities of avertisol in the central high lands of Ethiopia. African Journal of Environmental Science and Technology, 5(12): 008-1016 (2011)

75. Thomas, G.A., Dalal, R.C., \& Standley, J., No-till effects on organic matter, $\mathrm{pH}$, cation exchange capacity and nutrient distribution in a Luvisol in the semi-arid subtropics. Soil and Tillage Research, 94: 295-304 (2007)

76. Paustian, K.A.O.J.H., Andrén, O., Janzen, H.H., Lal, R., Smith, P., Tian, G., Tiessen, H., Noordwijk, M.V. and Woomer, P.L., Agricultural soils as a sink to mitigate $\mathrm{CO} 2$ emissions. Soil use and management, 13(s4), 230-244 (1997)

77. Lal, R. Managing soils and ecosystems for mitigating anthropogenic carbon emissions and advancing global food security. BioScience, 60(9): 708-721 (2010)

78. Krishan, G., Kumar, S., \& Saha, S.K., Significance of studying microbial diversity and its relevance. Annals of Forestry, 15(1): 154-156 (2007)

79. Bronick, C.J. and Lal, R., Soil structure and management: a review. Geoderma, 124(1), 3-22 (2005)

80. Wall, D.H. and Moore, J.C., Interactions underground: soil biodiversity, mutualism, and ecosystem processes. BioScience, 49(2), 109-117 (1999)

81. Krishan, G. \& Saha, S.K., Integrated plant nutrition system (IPNS)-A practice for sustainable agriculture resource management. Indian Journal of Environment and Ecoplanning, 15(1-2): 15-28 (2008) 